\title{
Acid rock drainage source control opportunities at the Red Dog Zinc and Lead Mine, USA
}

\author{
J.L. Clark Teck Alaska Incorporated, USA \\ D. Christensen O'Kane Consultants Inc., Canada \\ B. Lum Teck Resources Ltd., Canada
}

\begin{abstract}
Located in the Western Brooks Range of Alaska, the Red Dog Mine is one of the most northerly active, zinclead open pit mines. Mining of high grade zinc and lead sulphide ores results in the production of waste rock that is mostly acid generating. Control and treatment of acid rock drainage (ARD) from waste rock and pit walls is one of the most critical environmental activities at the mine site. The treatment of ARD water from the main waste rock stockpile, containing total dissolved solids (TDS) values as high as 90,000 $\mathrm{mg} / \mathrm{L}$, is expensive today and it will be a major component of post-closure costs in the future. In order to reduce the amount of water to be treated in the near and longer term, Red Dog has initiated programs to minimise the production of $A R D$ at the source, through construction of engineered cover systems on waste rock stockpiles and will make improvements in the collection and treatment of the ARD waters from the stockpiles, to allow for more efficient removal of TDS from the impacted waters.
\end{abstract}

\section{Introduction}

Teck Alaska Incorporated (Teck), Red Dog zinc, lead, and silver mine is located in the Western Brooks Range of Northwestern Alaska, USA. Mining of high grade zinc and lead sulphide ores since 1989 has resulted in the production of large quantities of waste rock that is mostly acid generating. Control and treatment of acid rock drainage (ARD) from waste rock and pit walls, although not considered crucial in 1989, has become one of the more critical environmental activities at the mine site. The treatment of the ARD water is expensive presently and is a major component of the US\$ 305 million financial assurance set aside for closure and post-closure costs.

This paper reports on recent efforts to control, and collect for treatment, ARD from the waste rock stockpiles through programmes to minimise the production of ARD at the source, construction of engineered cover systems, and improvements in the collection system for treatment of the ARD waters.

\section{Geology}

The Red Dog zinc, lead and silver deposits are hosted in Mississippian sedimentary rock of the Kuna Formation of the Lisburne Group (Dumoulin et al., 2004). More specifically, the ore is concordant within the Ikalukrok unit of the Kuna Formation. The massive sulphide ore appears to have formed as sub-seafloor replacement of calcareous radiolarite which is interbedded with deep-water siliceous black shale. The deposit is capped by barite which formed either very near the sea floor or just above the sea floor. The barite cap is mineralised with zinc and lead at its base. Veins of sphalerite, galena and pyrite/marcasite, thought to be feeders to the concordant mineralisation, occur most frequently as fracture fillings in silicified footwall shale to the main mineralisation (Kelly et al., 2004).

Footwall to the host Ikalukrok unit is the Kivalina unit composed of interbedded black to grey calcareous shale and grey limestone. The Kivalina unit is in places, weekly mineralised with trace amounts of disseminated sphalerite but is generally less than $1,000 \mathrm{mg} / \mathrm{kg}$ combined zinc and lead.

Overlying the ore host Ikalukrok unit is the Pennsylvanian, Siksikpuk Formation, composed of siliceous red and green shale, followed by erosional remnants of Triassic, Otuk Formation, chert and shale and then by the Cretaceous, Okpikruak Formation, composed of aluminous black shale and sandstone. 


\section{Waste rock stockpile}

Because Red Dog zinc ore grades are amongst the highest in the world, with zinc feed grades averaging over $20 \%$ in many years the average waste rock often exceeds $1.5 \%$ zinc. As an example, in 2010 the waste rock averaged $1.5 \%$ zinc, $1.3 \%$ lead, and 3.3\% iron. The main waste rock stockpile contains 52 million tonnes of this highly mineralised waste covering an area of approximately 100 hectares. The main waste rock stockpile was constructed from 1989 through the present, by end dumping in lifts of 15 to $23 \mathrm{~m}$ in height upon and parallel to a west sloping hill south of the main pit. The bedrock beneath the stockpile is Okpikruak shale which was initially frozen but has now thawed from the heat generated within the stockpile. Drainage from the main waste rock stockpile flows westward to the tailings storage facility (TSF).

The climate in the area of the mine is semi-arid polar tundra with an average precipitation of $460 \mathrm{~mm}$ per year. In an average year $550,000 \mathrm{~m}^{3}$ of precipitation falls on the stockpile. As the precipitation moves through the stockpile it carries dissolved oxygen, oxidising sphalerite, pyrite and marcasite within the waste with the assistance of sulphur oxidising bacteria. The oxidation of the sulphides produces runoff with $\mathrm{pH}$ as low as 1.3 with leached metal content, expressed as total dissolved solids (TDS), as high as $90,000 \mathrm{mg} / \mathrm{L}$ in the runoff from the main waste rock stockpile.

High TDS waters from the main waste rock stockpile as well as drainage from all active mining areas are collected into the TSF with an average TDS concentration of 5,200 mg/L. Waters from the TSF are treated using conventional high density sludge methods for discharge into Red Dog Creek to a level of about 4,500 mg/L TDS. Discharge into Red Dog Creek is limited by Red Dog's NPDES permit to in-stream TDS level of $1,500 \mathrm{mg} / \mathrm{L}$ in Red Dog Creek after passing through a mixing zone. In order to discharge the quantity of the annual precipitation falling throughout the entire mine area, levels of TDS in the discharge water must be minimised to allow the maximum water discharged while maintaining in-stream TDS limits.

Red Dog has initiated two programmes to decrease the TDS in the TSF, an engineered waste rock cover system and more efficient collection and pre-treatment of ARD from the main waste rock stockpile.

\section{$4 \quad$ Waste rock cover system}

An engineered cover system for waste rock stockpiles at Red Dog is necessary to reduce the infiltration of oxygenated precipitation into the waste rock and to help maintain a low oxygen atmosphere within the stockpile. Limiting the inflow of precipitation into the stockpile reduces the flow rate of ARD from the stockpile and permits more efficient collection and treatment of the runoff. Cover systems also provide a growth media for revegetation.

The choice of cover systems for waste rock stockpiles is primarily contingent on annual precipitation. The semi-arid polar tundra climate at the Red Dog Mine suggested the use of a store and release cover system rather than a wet cover system. Teck retained O'Kane Consultants Inc. (OKC) to assist in the development of a store and release cover system and to test different cover materials. OKC modelled four cover systems using Red Dog weather information in numerical simulations using the saturated-unsaturated VADOSE/W model. Models estimated net percolation of $15 \%$ of annual precipitation over a four-year simulation period.

The non-glaciated terrain surrounding the Red Dog Mine lacks thick unmineralised soil, or glacial materials acceptable for the construction of engineered cover systems. Unmineralised shale $(<1,000 \mathrm{mg} / \mathrm{kg}$ zinc $)$ from the excavation of the deposits is the only source of abundant material for building covers. Fortunately, two formations contain shale that provides the necessary geotechnical specifications, and physical and nutrient requirements for plant growth.

The calcareous Kivalina unit shale has high neutralisation potential (median $\left.250 \mathrm{kgCaCO}_{3} / \mathrm{t}\right)(\mathrm{SRK}$ Consulting, 2003). The thinly laminated shale is quickly broken down by carbonic acid in rain water to form a black material containing abundant fines which can be compacted to densities greater than $2,200 \mathrm{~kg} / \mathrm{m}^{3}$ to provide an adequate infiltration barrier (OKC, 2003). Okpikruak Formation shale is post-mineralisation aluminous shale with very low metal values but with almost no acid neutralisation potential (SRK Consulting, 2003). The Okpikruak shale also decomposes rapidly to form material containing abundant fines which can be compacted to provide an adequate infiltration barrier. Test plots established by the Alaska Plant Materials Center on weathered rock from both rock types provided good plant growth and confirmed 
observations of the abundant plant growth growing on these rock units on hillsides in the area of the mine (Nolen, 2005).

\subsection{Initial small-scale cover tests}

In 2005, under the supervision of OKC, cover trials were constructed on lined waste rock cells that had previously been used for bactericide application experiments. Three covers were tested in horizontal configuration, one metre uncompacted Kivalina shale over uncompacted waste rock, one metre uncompacted Kivalina shale over compacted waste and one meter uncompacted Kivalina shale over a Geosynthetic clay liner (GCL) over compacted waste rock. A fourth cell was left uncovered as a bare waste rock control. Each cell was instrumented with automated temperature, soil water potential (matric suction) and water content sensors to monitor in situ temperature and moisture conditions and all leach water was collected in tanks for volume measurement and chemical sampling. During the 2008 monitoring year, net infiltration was lowest in the cell with the GCL liner, approximately $6 \%$ of the $380 \mathrm{~mm}$ of total precipitation. In comparison net infiltration was $10 \%$ for the cell with compacted waste rock overlain by $1 \mathrm{~m}$ uncompacted Kivalina shale, $11 \%$ for the monolithic $1 \mathrm{~m}$ uncompacted Kivalina shale cover system, and approximately $30 \%$ for the bare waste rock control. The small-scale trials indicated that the Kivalina shale covers were capable of decreasing precipitation infiltration by about $70 \%$ over the bare waste rock surface (OKC, 2009).

\subsection{Large-scale cover test}

In 2008, Teck began construction of large-scale cover test on the 11 ha oxide waste rock stockpile. This stockpile contains highly reactive oxidised ore from the top of the main deposit that is not suitable for processing by floatation methods. OKC was selected to design the cover system and instrumentation for the test. The cover system chosen for this test consisted of compacted waste rock overlain by $0.5 \mathrm{~m}$ compacted Kivalina shale followed by $0.5 \mathrm{~m}$ of uncompacted Kivalina shale as a growth medium material. The Kivalina shale was obtained from the overburden stockpile, a stockpile constructed of materials stripped from the upper surface of the main deposit. The upper surface of the stockpile was graded to an eastward slope of $4.5 \%(22: 1)$ to prevent ponding of precipitation. The sides of the stockpile were graded to a slope of $33 \%$ (3:1). The oxide waste rock stockpile was hydro-seeded with native grasses in fall of 2008 and spring of 2009.

\subsubsection{Instrumentation}

The following instrumentation was installed on the flat upper surface of the oxide waste rock stockpile and the west slope of the stockpile to assess the performance of the cover systems:

- A weather station on the oxide waste rock stockpile consisting of:

- A tipping bucket rain gauge to continuously monitor rainfall.

- An air temperature sensor.

- Two (2) net radiometers to monitor net radiation at each instrument location.

- Two (2) sonic depth rangers for measuring the depth of the snowpack above the cover system at each instrument location.

- Two (2) automated lysimeters for measuring the volume of water percolating through the cover system.

- Two (2) automated monitoring stations for measuring in situ volumetric water content, suction, i.e. negative pore-water pressure, and temperature in the cover / upper waste rock profile.

- Two (2) automated monitoring stations for measuring in situ volumetric water content in the cover/ upper waste rock profile.

- A flume box containing a trapezoidal flume for continuously measuring the volume of runoff from the surface of the cover system. 
Monitoring data was recorded in a CR1000, downloaded monthly by Teck technicians and sent to OKC for processing and analysis. Monitoring of the instrumentation is expected to continue through 2013.

\subsubsection{Monitoring results}

The first two years of monitoring indicates that the covers are performing close to design specifications. Percolation rates in 2008-2009 were 16-17\% of annual precipitation (OKC, 2010a) and percolation rates in 2009-2010 were $10-11 \%$ of annual precipitation (OKC, 2010b). Figure 1 The 2009-2010 winter had the least snowpack measured at Red Dog since the mine opened in 1989 and therefore the percolation rates from 2009-2010 suggest the lower boundary of percolation rates anticipated for the oxide waste rock stockpile cover system (OKC, 2010b).

2009

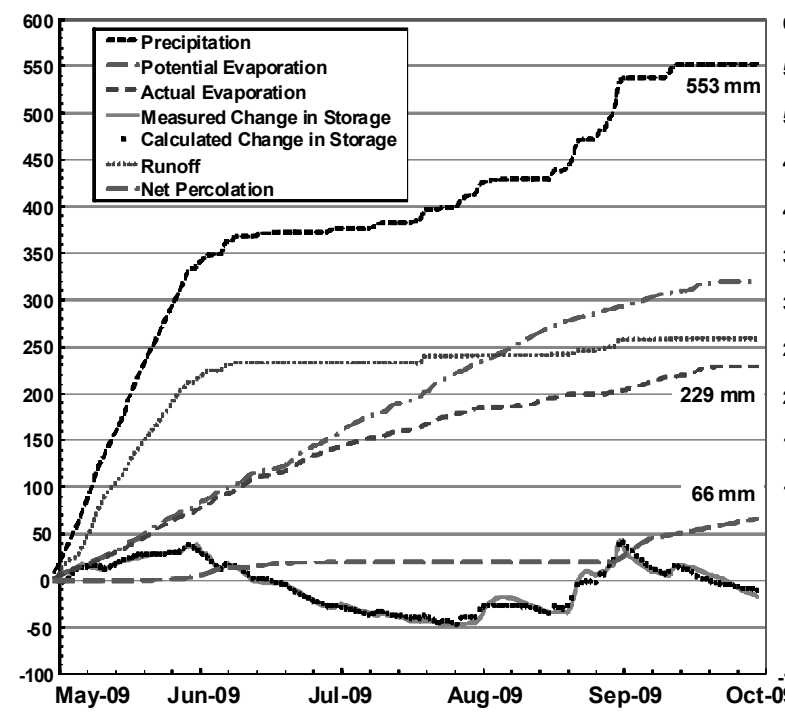

2010

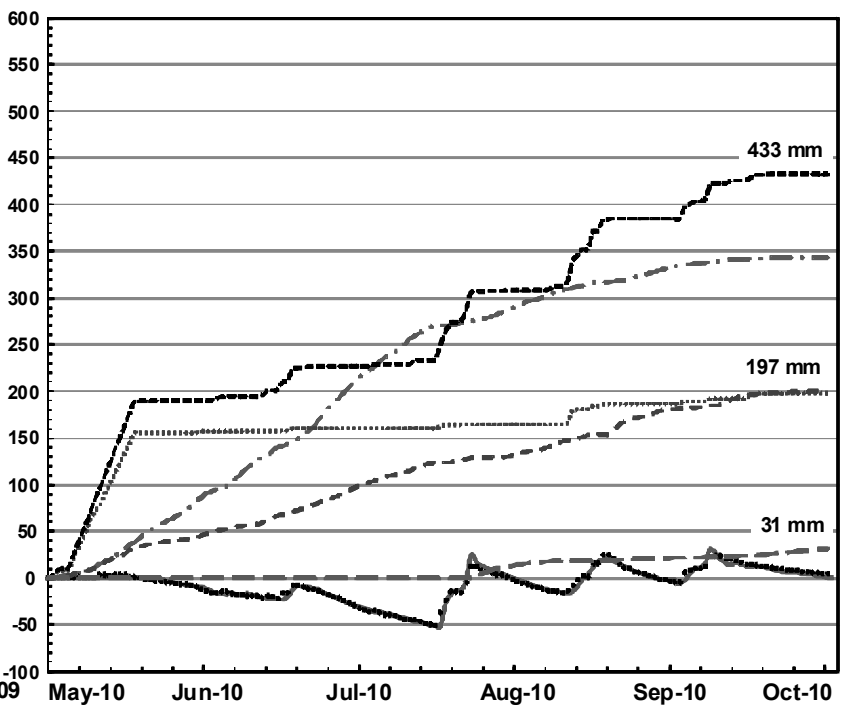

Figure 1 Frost free period water balance oxide stockpile West Station 2009 and 2010

\subsection{Covers on the main waste rock stockpile}

When mining of the Red Dog main pit is complete, in 2011, the main waste rock stockpile will be closed to further dumping. Waste from the Aqqaluk Pit will be placed into the mined-out main pit. Unless continued monitoring of the oxide waste rock stockpile indicates problems with the two-layer cover system, it is anticipated that a similar cover system will be applied to the main waste rock stockpile. In anticipation of this activity, the western and southern slopes of the main waste rock stockpile were recontoured to slopes of 33\% (3:1) in 2010. Prior to the installation of final cover systems, Teck will apply additional landform features to create more natural and erosion stable landforms. Final cover application will be delayed until 2012 at which time acceptable Kivalina shale cover material will be mined from the Aqqaluk pit for application on the main waste rock stockpile.

\section{Improve ARD collection from main waste rock stockpile}

In 2005 Teck installed four shallow, $2 \mathrm{~m}$ deep sumps, along the base of the main waste rock stockpile to collect runoff before it flows into the TSF for treatment in water treatment plant \#3 (WTP-3). WTP-3 is specifically designed for treatment of high TDS water before it enters the TSF. Reaction kinetics of adding lime to these high TDS waters make treatment more efficient in WTP-3 than treating the ARD water after it is diluted in the TSF.

Water balance calculations indicated that the ARD collection system sumps installed along the base of the main waste rock stockpile were only collecting approximately $15 \%$ of the $550,000 \mathrm{~m}^{3}$ of precipitation which fell on the stockpile annually. The annual TDS load of this runoff is estimated at 23,000 tonnes and contributes nearly $75 \%$ of the annual TDS load in the TSF. 
A thermistor string installed in 2005 to gather geotechnical information for the construction of an extension of the TSF dam, indicated on March 25, 2006, the passage of $9.3^{\circ} \mathrm{C}$ water at a depth of $8.5 \mathrm{~m}, 6.5 \mathrm{~m}$ below the bottom of a nearby collection sump. Expected temperature at this depth should have been $-1.5^{\circ} \mathrm{C}$ (permafrost temperature). The presence of water warmer than expected below the sump and the calculations which showed the collection of only $15 \%$ of precipitation lead to the decision by Teck to investigate the flow of the warm, high TDS water from the base of the main waste rock stockpile in 2010.

\subsection{Airborne resistivity mapping}

Fugro Airborne Surveys was contracted to conduct an airborne magnetic and RESOLVE® survey of the mine property. The RESOLVE system is a helicopter-borne frequency domain electromagnetic (EM) system often used to map near surface earth resistivities and horizontal layered geology. Airborne, multi-coil, multifrequency electromagnetic systems had been successful in mapping sub-surface contaminated groundwater flow at the Sulphur Bank Mercury Mine near Clearlake, CA, USA (Hammack et al., 2002).

In May 2010, a total of 684 line kilometres were flown on an orthogonal grid with a line spacing of $50 \mathrm{~m}$. One flight line direction was flown at an azimuth of $013^{\circ}$, parallel to power lines and pipelines along the base of the main waste rock stockpile to minimise the interference from those features on the mapping of the subsurface (Fugro Airborne Surveys, 2010).

The survey was successful in mapping the highly conductive tailings and water in the TSF, the main waste rock stockpile and four apparent flow paths of sub-surface ARD flow from the main waste rock stockpile to the TSF. Four primary areas of moderate apparent resistivity lows were identified along the west margin of the main waste rock stockpile corresponding to areas of pre-mining topographic lows (Figure 2).

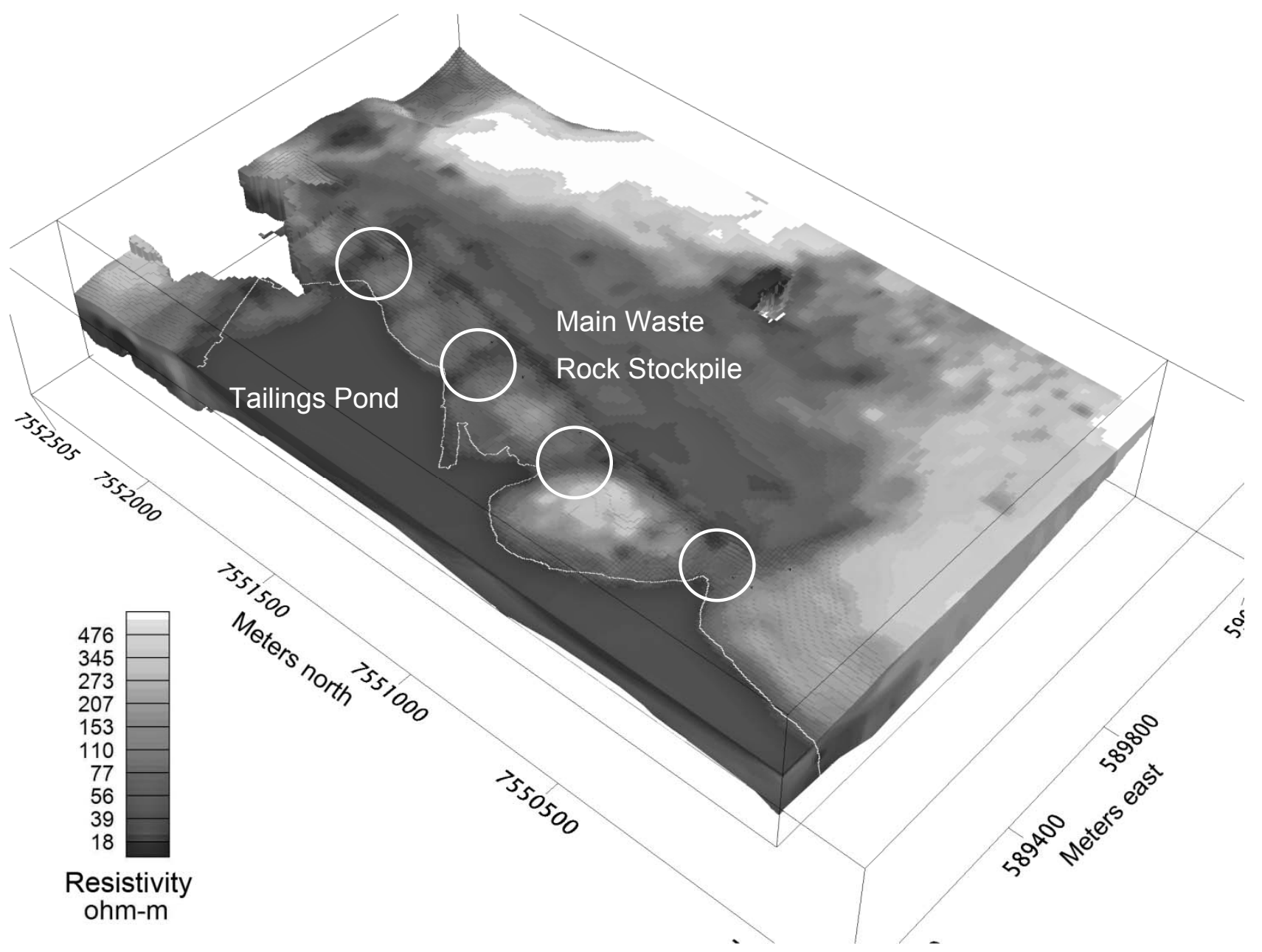

Figure 2 Apparent resistivity at $320 \mathrm{~m}$ elevation showing areas of probable ARD flow to the tailings pond in circled areas 


\subsection{Ground resistivity mapping}

In order to obtain better resolution of the four potential flow areas identified in the airborne survey, ground electromagnetic surveys were contracted from Golder Associates (Golder). Golder surveyed two survey lines along the west and south margin of the main waste rock stockpile using the following methods:

- High resolution DC resistivity survey called electrical resistivity imaging (ERI). This survey was done using an IRIS Instruments Syscal Pro 96 Channel ERI System.

- Two high lateral resolution EM surveys using Geonics EM31 and Geonics EM34 systems.

- Very low frequency (VLF) EM survey using the ABEM Wadi VLF EM receiver.

The resistivity survey and three EM surveys together provided a high resolution $2 \mathrm{D}$ section image that identified the subsurface ARD flows as low resistivity zones (Golder Associates Inc., 2010).

\subsection{Auger borehole drilling}

To ground truth the resistivity surveys, Dowl HKM was contracted to drill test borings along the western base of the main waste rock stockpile. A total of 15 auger holes were drilled to bedrock or auger refusal in June 2010 using a CME-45 skid-mounted drill rig.

The following tests were conducted on samples taken at $1.5 \mathrm{~m}$ intervals in each bore hole:

- Visual classification of soil parameters.

- Moisture content.

- Particle size distribution.

- Plasticity index tests.

Slotted $19 \mathrm{~mm}$ PVC pipe was placed in each hole and groundwater levels were measured after waiting 24 hours for equilibrium. Groundwater was encountered in 8 of the 15 holes at depths of 1.8 to $5.3 \mathrm{~m}$ perched on weathered Okpikruak Formation bedrock. Sealed $19 \mathrm{~mm}$ PVC pipe was placed in each hole with thermistor strings placed inside the casing. Nodes on the thermistor strings varied in spacing from $0.6 \mathrm{~m}$ to $1.5 \mathrm{~m}$. Thermistor readings from two holes, 102 and 108, indicated increasing temperatures at depth suggesting subsurface warming from the flow of warm ARD water from the main waste rock stockpile (Dowl HKM, 2010) (Figure 3). 


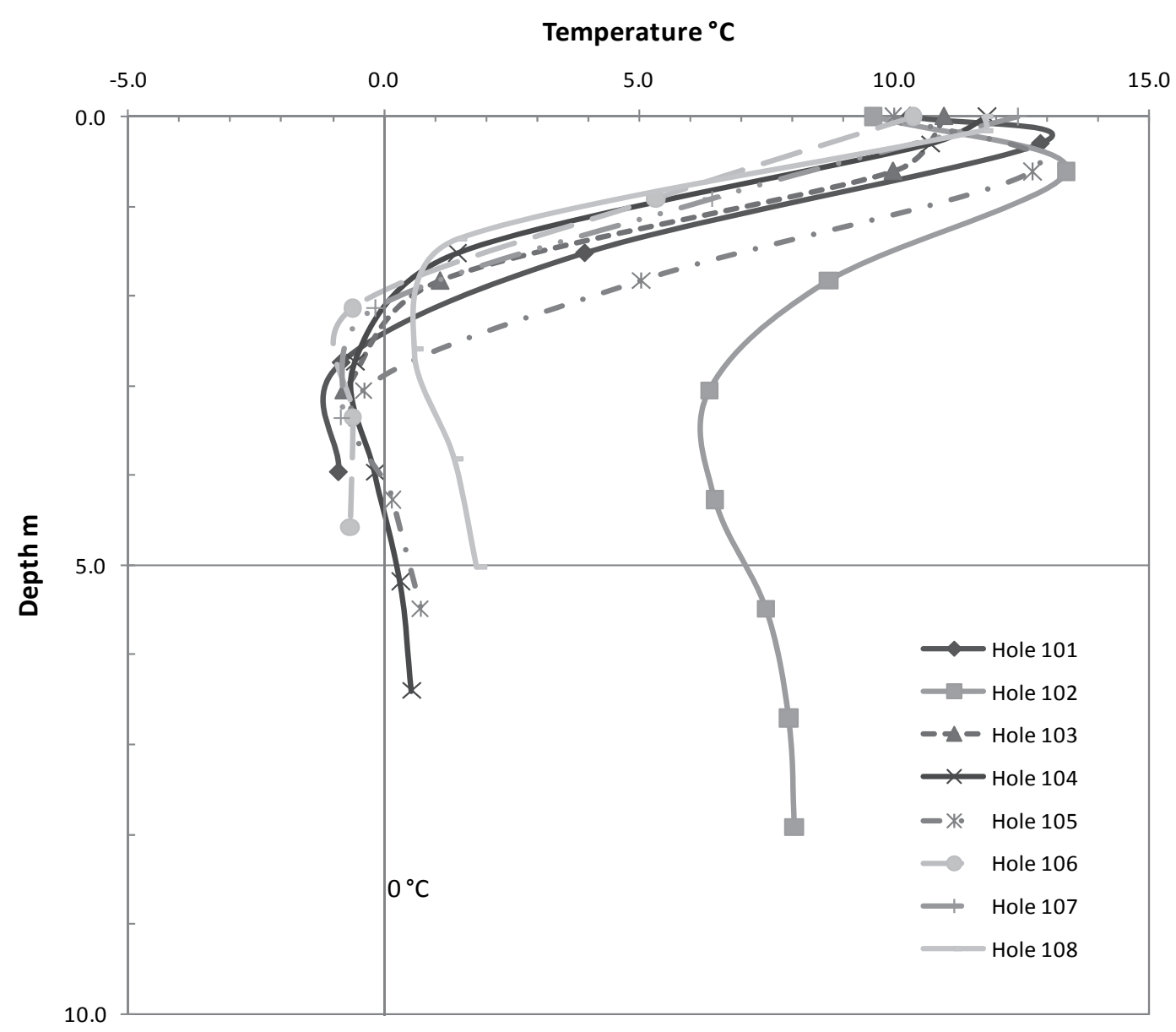

Figure 3 Temperature profiles along the base of the main waste rock stockpile June 19, 2010

\subsection{Dewatering wells}

Resistivity surveys and auger drilling along the base of the main waste rock stockpile appear to confirm that the shallow sumps previously installed to collect ARD from the stockpile may not be collecting a significant portion of the annual runoff. Teck chose to supplement the four shallow sumps with wells drilled into bedrock in the areas of low resistivity detected by the geophysical surveys where the auger drilling encountered ground water flow. These wells had not been fully commissioned at the time of this paper. If the individual wells are not adequate to collect a significant quantity of the ARD from the stockpile grout curtain walls or deep French drains may be have to be added.

\section{Conclusions}

Control of TDS at the source with the installation of appropriate cover systems and the efficient collection of ARD runoff from stockpile areas is essential for the Red Dog Mine to continue to discharge adequate water to meet its water balance objectives for closure. Cover systems installed to date have shown significant reduction in infiltration of precipitation. Application of similar cover systems to the rest of the main waste rock stockpile should result in decreased quantities of ARD to treat. Geophysical surveys of the main waste rock stockpile and geotechnical drilling have identified areas where enhanced collection systems may be installed to intercept ARD for treatment. Treatment of high TDS waters from the waste rock stockpiles prior to dilution in the TSF will allow Teck to reduce the TDS in its discharge water and increase the volume of water discharged to meet its water balance targets. 


\section{Acknowledgements}

We thank Teck Alaska Incorporated for permission to present this study and to the staff who contributed their time and efforts. In particular, we thank Hugh Stewart for his support of the geophysical and drilling programmes. We also thank Yuri Mironenko, Jorje Naranjo of Fugro, Peter Fahringer and Matthew Benson of Golder Associates, and Keri Nutter of Dowl HKM upon whose work we have reported.

\section{References}

Dowl HKM (2010) Geotechnical Data Summary Report Mine Waste Dump Red Dog Mine, Alaska, prepared for Teck Alaska Incorporated by Dowl HKM, Report No. 5096, Anchorage, July 2010 (unpublished, cited with permission), $13 \mathrm{p}$.

Dumoulin, J.A., Harris, A.G., Blome, C.D. and Young, L.E. (2004) Depositional Settings, Correlation, and Age of Carboniferous Rocks in the Western Brooks Range, Alaska Geology, Vol. 99, November 2004, pp. 1355-1384.

Fugro Airborne Surveys (2010) Logistics and Processing Report, Airborne Magnetic and RESOLVE Survey, Red Dog Minesite, Alaska, prepared for Teck American Incorporated by Fugro Airborne Surveys, Job 10035, Mississauga (unpublished, cited with permission), $28 \mathrm{p}$.

Golder Associates Inc. (2010) Ground Geophysical Investigation, ARD Ground Water Mapping Program Red Dog Mine, Alaska, prepared for Teck Alaska Incorporated by Golder Associates Inc., Project No. 103-93199.300, Redmond, (confidential, cited with permission), $10 \mathrm{p}$.

Hammack, R.W., Veloski, G.A., Sams, III, J.I. and Mabie, J.S. (2002) The Use of Airborne Magnetic and EM Conductivity Surveys to Locate Groundwater Flow Paths at the Sulphur Bank Mercury Mine Superfund Site, Proceedings of Reclamation with a Purpose, a joint conference of ASMR 19th Annual National Conference and IALR 6th International Conference, R. Barnhisel and M. Collins (eds), June 9-13 2002, Lexington KY, Published by ASMR, Lexington, KY, USA, pp. 259-274.

Kelly, K.D., Leach, D.L., Johnson, C.A., Clark, J.L., Fayek, M., Slack, J.F., Anderson, V.M., Ayuso, R.A. and Ridley, W.I. (2004) Textural, Compositional, and Sulfur Isotope Variations of Sulfide Minerals in the Red Dog Zn-PbAg Deposits, Brooks Range, Alaska: Implications for Ore Formation, Economic Geology, vol. 99, November 2004, pp. 1509-1532.

Nolen, A. (2005) Report for 2005 trip, prepared for Teck Cominco Alaska by Alaska Plant Materials Center, Palmer, unpublished, $1 \mathrm{p}$.

O'Kane Consultants Inc. (OKC) (2003) Investigation of the Surface Compaction of the Main Waste Stockpile and the Overburden Stockpile at Teck Cominco Alaska - Red Dog Operations, prepared for Teck Alaska by O'Kane Consultants Inc., Report No. 694-02, Saskatoon (unpublished, cited with permission), 38 p.

O'Kane Consultants Inc. (OKC) (2009) Red Dog Operations - Little Bear Waste Rock Cell Cover Trials Performance Monitoring Summary Report, prepared for Teck Alaska by O'Kane Consultants Inc., Report No. 694/2-03, Saskatoon (unpublished, cited with permission), $20 \mathrm{p}$.

O'Kane Consultants Inc. (OKC) (2010a) Teck Resources - Red Dog Mine Oxide Stockpile Full-Scale Cover System 2008-09 Annual Performance Monitoring Report, prepared for Teck Alaska by O'Kane Consultants Inc., Report No. 694/3-03, Saskatoon (unpublished, cited with permission), 23 p.

O'Kane Consultants Inc. (OKC) (2010b) Teck Resources - Red Dog Mine Oxide Stockpile Full-Scale Cover System 2009-10 Annual Performance Monitoring Report, prepared for Teck Alaska by O'Kane Consultants Inc., Report No. 694/3-04, Saskatoon (unpublished, cited with permission), 23 p.

SRK Consulting (2003) Red Dog Mine Closure and Reclamation Plan, D1 Consolidation of Studies on Geochemical Characterization of Waste Rock \& Tailings, prepared for Teck Alaska Incorporated, $48 \mathrm{p}$. 